\title{
Correlation among Bone Health Profile, Vitamin D Status and Body Weight among Children and Adolescents in the Western Region of Saudi Arabia
}

Abdulmoein Eid Al-Agha*, Abdalla Fawaz Mahmoud, Abdullah Ahmed Alshein, Nuha Hazem Bukhari, Majed Abdulkarim Alaama, Bashaer Mahboub Alalwani, Ruba Ateeq Alshaikh

Department of Pediatrics, King Abdul-Aziz University Hospital, Kingdom of Saudi Arabia

\begin{abstract}
Objective: Vitamin $D$ deficiency related to obesity has significantly increased over the past 15 years and this has increased the risk for bone disease in children and adolescents. A sedentary lifestyle, with limited participation in outdoor activities, could exacerbate the effects of obesity on vitamin D deficiency. Therefore, the aim of our study was to evaluate the relationship between overweight/obesity and vitamin D deficiency among children in the western region of Saudi Arabia who have a relatively sedentary lifestyle due to high year-round temperatures.
\end{abstract}

Methods: We conducted a cross-sectional study including 218 participants (114 girls, 104 boys), 2 to 18 years old, evaluated in our ambulatory endocrine clinics in Jeddah, Saudi Arabia, between September 2015 and March 2016. Serum levels of vitamin D, phosphorus, calcium and alkaline phosphates were evaluated in relation to body weight.

Results: The mean age among children in our study group was $9.9 \pm 3.9$ years. A prevalence rate of vitamin $D$ deficiency/insufficiency of $97.5 \%$ was identified (156/218 participants), with normal serum levels of vitamin $D$ identified in only $4 / 218$ participants $(2.5 \%)$. Vitamin D levels were inversely related to body weight. High levels of alkaline phosphates were identified in $88.2 \%$ of participants, with levels of calcium and phosphorus being within normal ranges overall.

Conclusion: Based on our results, increased surveillance for vitamin $\mathrm{D}$ deficiency/insufficiency and alkaline phosphates levels in children who are overweight and obese should be considered. Moreover, as children and adolescents in the western region of Saudi Arabia typically have low sun exposure due to limited outdoor activities, vitamin D supplementation, as indicated by screening outcomes, could improve bone health outcomes in children who are overweight and obese.

Keywords: Vitamin D deficiency; Obesity; Bone health; Pediatrics

\section{Introduction}

The prevalence rate of obesity among children and adolescents has rapidly increased over the past 10 to 15 years, with an associated increase in the prevalence of vitamin D deficiency [1-4]. Considering that obesity is a risk factor for vitamin D deficiency [5-7] and that vitamin $\mathrm{D}$ is necessary for absorption of calcium in gut to maintain normal levels of serum calcium and phosphorous [8], then obesity is now considered as a risk factor for poor bone formation in children and adolescents. Vitamin D deficiency is further exacerbated by a decrease in the dietary intake of vitamin $\mathrm{D}$ and a low participation in outdoor activities [9]. The corollary effect of decreased outdoor activities on vitamin $\mathrm{D}$ deficiency could be a significant factor for children living in the western region of Saudi Arabia, where the temperature is high year round and a sedentary lifestyle is, therefore, the norm [10]. However, the possible correlation between a change in lifestyle, obesity, and vitamin D deficiency has only been considered in few studies [11-13]. Therefore, the aim of our study was to evaluate the relationship between overweight and vitamin D deficiency among children in the western region of Saudi Arabia who have a relatively sedentary lifestyle.

\section{Methods \\ Participants}

We are conducted a cross sectional study including 218 participants (114 girls, 104 boys), 2 to 18 years old, who were evaluated in our ambulatory endocrine clinics in Jeddah, Saudi Arabia, between
September 2015 and March 2016. Body weight was measured and used to classify participants based on the standard deviation of their body weight from age norm references, using the Boston Hospital Children Growth Calculator [14]. Serum levels of hydroxyvitamin D 25(OH)D, phosphorous, calcium and alkaline phosphates were measured using standard blood laboratory tests at King Abdul-Aziz University Hospital by using LIAISON $25 \mathrm{OH}^{\circ}$ Vitamin D assay, and Chemistry tests for calcium, phosphorus and ALP were done on Dimension instrument (Siemens Dimension RXL).

Our methods were approved by The Research Ethics Committee at King Abdul-Aziz University Hospital and participants, or their parent(s)/guardian(s), provided informed consent as appropriate for age.

\section{Laboratory tests}

The following normal ranges for serum levels of hydroxyvitamin

${ }^{*}$ Corresponding author: Al-Agha A, Department of Pediatrics, King Abdul-Aziz University Hospital, Jeddah 21589, P.O.Box 80215, Kingdom of Saudi Arabia, Saudi Arabia, Tel: 9662 6408353; Fax: 9662640 3841; E-mail: aagha@kau.edu.sa

Received August 30, 2016; Accepted September 22, 2016; Published Septembe 29, 2016

Citation: Al-Agha AE, Mahmoud AF, Alshein AA, Bukhari NH, Alaama MA, et al. (2016) Correlation among Bone Health Profile, Vitamin D Status and Body Weight among Children and Adolescents in the Western Region of Saudi Arabia. J Pat Care 2: 122. doi: 10.4172/2573-4598.1000122

Copyright: (c) $2016 \mathrm{Al}-\mathrm{Agha} \mathrm{A}$, et al. This is an open-access article distributed unde the terms of the Creative Commons Attribution License, which permits unrestricted use, distribution, and reproduction in any medium, provided the original author and source are credited. 
Citation: Al-Agha AE, Mahmoud AF, Alshein AA, Bukhari NH, Alaama MA, et al. (2016) Correlation among Bone Health Profile, Vitamin D Status and Body Weight among Children and Adolescents in the Western Region of Saudi Arabia. J Pat Care 2: 122. doi: 10.4172/2573-4598.1000122

D $25(\mathrm{OH}) \mathrm{D}$, phosphorous, calcium and alkaline phosphates were used as a reference. For vitamin D, a serum concentration of 51$75 \mathrm{nmol} / \mathrm{L}$ was considered as the normal range, with insufficiency/ deficiency defined by a concentration $\leq 25-50 \mathrm{nmol} / \mathrm{L}$. For calcium levels, a concentration of $2.2-2.62 \mathrm{mmol} / \mathrm{L}$ was considered normal, with hypocalcaemia defined as $<2.2 \mathrm{mmol} / \mathrm{L}$. For phosphorus, a concentration of $0.8-1.6 \mathrm{mmol} / \mathrm{L}$ was considered normal, with a high serum concentration defined as $>1.6 \mathrm{mmol} / \mathrm{L}$. For alkaline phosphates has normal range defined as $50-136 \mathrm{mmol} / \mathrm{L}$ and the high serum level was defined as $>136 \mathrm{mmol} / \mathrm{L}$.

\section{Statistical Analysis}

All data were entered, coded, and analyzed using statistical package for social science (SPSS, version 16). The distribution of the data was evaluated for normality, with log-transformation used as required. The correlation between body weight $(\mathrm{kg})$ and levels of Vitamin D, Ca (calcium), Phos (Phosphorous), and ALP (Alkaline Phosphates) was evaluated independently for each variable. Qualitative variables were reported as proportions, with the mean \pm standard deviation calculated of quantitative variables. An independent sample $t$-test was used to evaluate vitamin $\mathrm{D}$ levels between males and females. For all analyzes, a p-value $<0.05$ was considered significant.

\section{Results}

Relevant characteristics of our study group and measured serum levels are reported in Table 1. Our study group consisted of 114 girls (52.3\%) and 104 boys (47.7\%), with a mean age of $9.9 \pm 3.9$ years $(95 \%$ confidence interval (CI), 9.3 to 10.4 years). Serum levels of $25(\mathrm{OH})$ $\mathrm{D} \leq 25-50 \mathrm{nmol} / \mathrm{L}$, indicative of vitamin $\mathrm{D}$ insufficiency/deficiency, were identified in $97.5 \%$ of participants, with a normal serum level of $25(\mathrm{OH}) \mathrm{D}$ identified in only $2.5 \%$ of participants (mean level, $26.4 \pm$ $10.4 \mathrm{nmol} / \mathrm{L}$ ). In regards to calcium, levels were normal in $91.7 \%$ of participants (199/217), with $18(8.3 \%)$ having hypocalcemia (mean level, $2.33 \pm 0.1 \mathrm{mmol} / \mathrm{dl})$. Serum levels of PHOS were normal level $69.4 \%$ of participants $(150 / 216)$, with hyperphosphatemea identified in $30.6 \%$ (66/216). Serum levels of ALP were assessed in 153 participants, with $11.8 \%$ showing normal levels, with $88.2 \%$ of participants having high serum levels of ALP (mean level, $241.6 \pm 85.8 \mathrm{mmol} / \mathrm{dl}$ ).

The inverse relationship between levels of ALP and PHOS is shown in Figure 1. The majority of participants had a high serum level of ALP, with a significant positive correlation between ALP levels and the standard deviation of weight from norm-reference values $(\mathrm{P}=0.007, \mathrm{R}=0.248)$. In contrast, $\mathrm{PHOS}$ levels were inversely correlated to the log-transformed weight values ( $\mathrm{P}=0.046, \mathrm{R}=0.144)$. The inverse relationship between body weight and serum levels of vitamin D is shown in Figures 2 and 3.

\begin{tabular}{|l|c|c|}
\hline Variables & Categories & $\mathbf{n ~ ( \% )}$ \\
\hline \multirow{2}{*}{ Sex } & Male & $104(47.7 \%)$ \\
\hline \multirow{2}{*}{ Vitamin D } & Female & $114(52.3 \%)$ \\
\hline \multirow{2}{*}{ Calcium } & Low $(\leq 50)$ & $156(97.5 \%)$ \\
\hline \multirow{2}{*}{ PHOS } & Normal $(>50)$ & $4(2.5 \%)$ \\
\hline \multirow{2}{*}{ ALP } & Low<2.2 & $18(8.3 \%)$ \\
\cline { 2 - 3 } & Normal $(2.2-2.62)$ & $199(91.7 \%)$ \\
\cline { 2 - 3 } & High>1.6 & $66(30.6 \%)$ \\
\hline
\end{tabular}

Table 1: Sex distribution of our study group and measured serum levels of vitamin $\mathrm{D}$, calcium, phosphorous and alkaline phosphates levels.

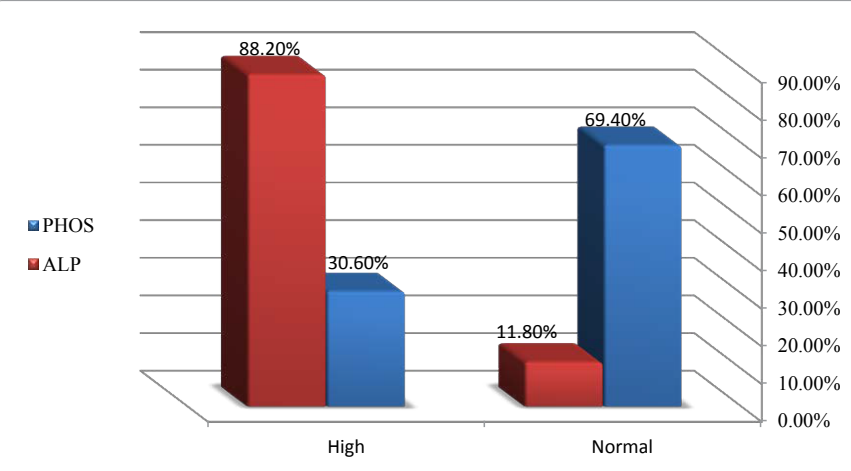

Figure 1: Bar graph showing the prevalence of $f$ high serum level ALP and normal serum level PHOS among the participants.

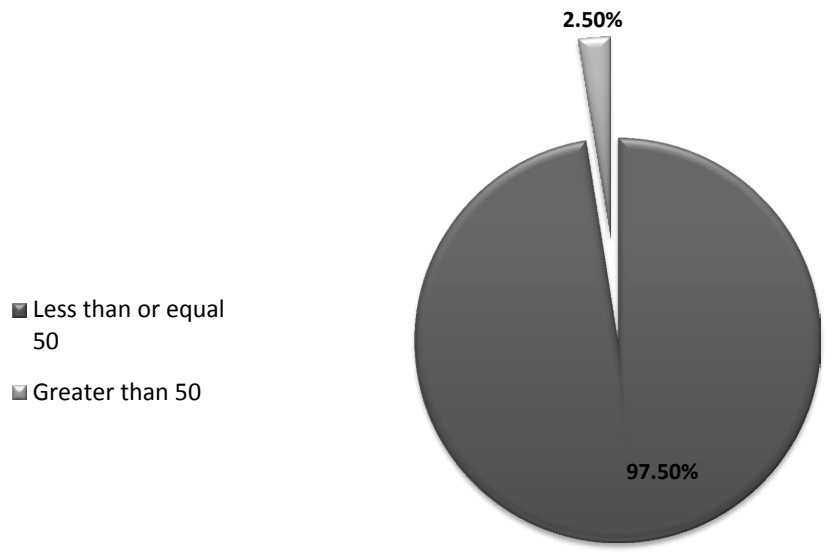

Figure 2: Correlation between vitamin $D$ levels and the log transformation of weight $(\mathrm{kg})$.

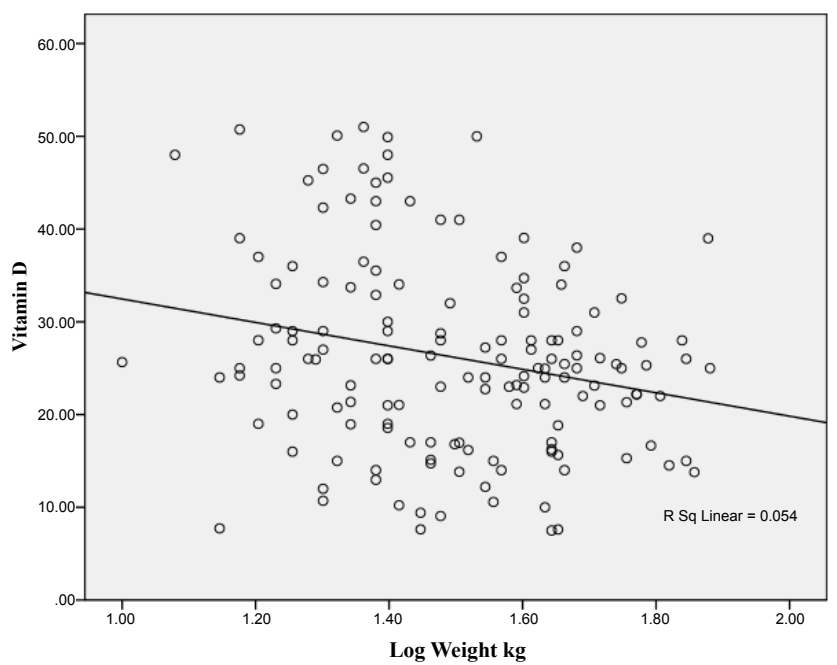

Figure 3: Proportional distribution of normal $>50 \mathrm{nmol} / \mathrm{L}$ and deficient/ insufficient $\leq 50 \mathrm{nmol} / \mathrm{L}$ serum levels of vitamin $D$.

\section{Discussion}

The high prevalence rate of vitamin D deficiency among children and adolescents in Saudi Arabia and the Middle East is a significant public health concern [15-19]. There is evidence that the rising incidence 
Citation: Al-Agha AE, Mahmoud AF, Alshein AA, Bukhari NH, Alaama MA, et al. (2016) Correlation among Bone Health Profile, Vitamin D Status and Body Weight among Children and Adolescents in the Western Region of Saudi Arabia. J Pat Care 2: 122. doi: 10.4172/2573-4598.1000122

Page 3 of 4

obesity in children may be contributing to the increasing prevalence of vitamin D deficiency/insufficiency in this population, where $22.2 \%$ of children are considered as being overweight, $8.9 \%$ obese and $2 \%$ severely obese [20]. A similar trend between increasing childhood obesity and vitamin D deficiency/insufficiency has been reported worldwide, $78 \%$ of children in France considered to have low serum levels of vitamin D, 65\% in Finland, $42 \%$ in Boston (United States) [10,21-25], 42\% in Beijing, $47 \%$ in Greece, $46.2 \%$ in Iran and 29\% in Switzerland [26-29]. A large United States based study of 12292 children and adolescents, 6 to 18 years old, evaluated between 2003 and 2006 (National Health and Nutrition Examination Survey), identified a prevalence rate of vitamin $D$ deficiency of $2 \%$ among children and adolescents with a healthy body weight, $29 \%$ among those who were overweight and $34 \%$ among those who were obese [30]. A study of 148 children ( 87 boys and 61 girls), 6 to 13 years old, in Saudi Arabia reported a vitamin D deficiency in $96.7 \%$ of females and $78.2 \%$ of males, with overall normal serum levels of calcium and phosphorus, but high levels of ALP [31]. Our findings are comparable to these previously reported prevalence rates. A study of 187 children with rickets and osteomalacia (64 boys and 123 girls), 3 months to 16 years old, in Saudi Arabia reported that the rising in serum ALP is a sensitive marker for screening the rickets and osteomalacia.

The climate in western region of Saudi Arabia is hot through all seasons and, consequently, children tend to limit their outdoor activities with the low exposure to sunlight exacerbating vitamin D deficiency/ insufficiency. A similar relationship between restricted outdoor activities and a high prevalence of vitamin D deficiency was reported among 402 children, 7 to 12 years old, in Malaysia where parents are concern about their children's safety when playing outside the home [8]. The importance of outdoor activities was raised by the American Academy of Pediatrics who recommended limiting television and computer use to $<2 \mathrm{~h}$ per day for young children to encourage outdoor play activities [32]. These outdoor activities should be proper for their age groups, i.e., by age 2 , toddlers in our study should be able to walk and run. They might be able to kick a ball and jump in place with both feet. By age, 3 and 4 toddlers can be balance briefly on one foot, kick a ball forward, throw a ball overhand, catch a ball with stiff arms, and pedal a tricycle. By age 6-18, these age groups, i.e., football, running, and basketball, can perform some common activities [33].

\section{Conclusion}

In our study, we report a high prevalence of vitamin D deficiency/ insufficiency among children and adolescents in the western region of Saudi Arabia, with this deficiency positively correlated to increased body weight. Moreover, low serum levels of vitamin D were associated to high serum levels of ALP. Increasing awareness regarding the risk for vitamin $\mathrm{D}$ deficiency through targeted public education initiatives could provide an effective way to improve vitamin D levels, and overall bone healthy, in children and adolescents in the western region of Saudi Arabia, rather than relying on screening and supplementation programs that are costly and may not be accessible by all children and adolescents. Promotion of outdoor activities and of a healthy diet is necessary components for achieving sufficient vitamin $\mathrm{D}$ levels for bone health in pediatrics.

\section{Acknowledgement}

The authors are grateful for the cooperation and work done by the statistical analyst Mrs. Ghiras Jamil Softah. We sincerely appreciate her patience and effort because this study would not been possible without her valuable contribution. The authors are also thankful to Dr. Sarah Ali Bashlawiv, Dr. Abrar Hassan Mohammed Dr. Wejdan Sueeleih Aljaberi, Dr. Abdullah Ahmed Kazm Al-khalaf, Dr.Amany Ali Alghamdi, Dr. Abdullah Mohammed Alsasi, Dr. Ahmed Alawamir, Dr. Abdullah Nizar Ghannam, Dr.Abdulwahab Mohammed Farag and Dr. Muhannad Talal Tolah for their cooperation in data collection and data entry.
We thank the reviewer for his/her through review and highly appreciate the comments and suggestions, which significantly contributed to improving the quality of publication.

\section{References}

1. Singh GK, Kogan MD, Van Dyck PC (2010) Changes in state-specific childhood obesity and overweight prevalence in the United States from 2003 to 2007 Arch Pediatr Adolesc Med 164: 598-607.

2. Ozfirat Z, Chowdhury TA (2010) Vitamin D deficiency and type 2 diabetes Postgrad Med J 86: 18-25.

3. Kayaniyil S, Vieth R, Retnakaran R, Knight JA, Qi Y, et al (2010) Association of vitamin $D$ with insulin resistance and beta-cell dysfunction in subjects at risk for type 2 diabetes. Diabetes Care 33: 1379-1381.

4. Wang TJ, Pencina MJ, Booth SL, Jacques PF, Ingelsson E, et al (2008) Vitamin $D$ deficiency and risk of cardiovascular disease. Circulation 117: 503-511.

5. Holick MF (2006) High prevalence of vitamin D inadequacy and implications for health. Mayo Clin Proc 81: 353-373.

6. Holick MF (2007) Vitamin D deficiency. N Engl J Med 357: 266-281.

7. Wortsman J, Matsuoka LY, Chen TC, Lu Z, Holick MF (2000) Decreased bioavailability of vitamin D in obesity. Am J Clin Nutr 2: 690-693.

8. Khor GL, Chee WS, Shariff ZM, Poh BK, Arumugam M, et al (2011) High prevalence of vitamin $D$ insufficiency and its association with BMl-for-age among primary school children in Kuala Lumpur, Malaysia. BMC Public Health 11: 95

9. Donath SM, Amir LH (2005) Breastfeeding and the introduction of solids in Australian infants: Data from the 2001 National Health Survey. Aust. NZ J Public Health 29: 171-175.

10. El-Hajj Fuleihan G, Nabulsi M, Choucair M, Salamoun M, Hajj Shahine C, et al (2001) Hypovitaminosis D in healthy schoolchildren. Pediatrics 107: E53.

11. Smotkin-Tangorra M, Purushothaman R, Gupta A, Nejati G, Anhalt H, Ten S (2007) Prevalence of vitamin D insufficiency in obese children and adolescents. J Pediatr Endocrinol Metab 20: 817-823.

12. Karonova T, Andreeva A, Nikitina I, Belyaeva O, Mokhova E, et al. (2016) Prevalence of Vitamin D deficiency in the North-West region of Russia: A crosssectional study. J Steroid Biochem Mol Biol pii: S0960-0760: 30073-30075.

13. Liu X, Xian Y, Min M, Dai Q, Jiang Y, et al. (2016)Association of 25-hydroxyvitamin D status with obesity as well as blood glucose and lipid concentrations in children and adolescents in China. Clin Chim Acta. 455:64-67.

14. http://growthcalc.chip.org/GrowthCalc

15. Al-Daghri NM, Al-Attas OS, Alokail MS, Alkharfy KM, Al-Yousef M, et al (2010) Severe hypovitaminosis $D$ is widespread in Saudi adults and is more common in non-diabetics than diabetics. Saudi Med J 31: 775-780.

16. Al-Daghri NM, Al-Attas OS, Alokail MS, Alkharfy KM, Yousef M, et al (2010) Hypovitaminosis D and cardiometabolic risk factors among non-obese youth. Cent Eur J Med 5: 752-757.

17. Al-Turki HA, Sadat-Ali M, Al-Elq AH, Al-Mulhim FA, Al-Ali AK (2008) 25-Hydoxyvitamin D levels among healthy Saudi Arabian women. Saudi Med J 29: $1765-1768$

18. Ardawi MS, Qari MH, Rouzi AA, Maimani AA, Raddadi RM (2011) Vitamin $D$ status in relation to obesity, bone mineral density, bone turnover markers and vitamin $\mathrm{D}$ receptor genotypes in healthy Saudi pre- and post-menopausal women. Osteoporos Int 22: 463-475.

19. Elsammak MY, Al-Wosaibi AA, Al-Howeish A, Alsaeed J (2010) Vitamin D deficiency in Saudi Arabs. Horm Metab Res 42: 364-368.

20. El Mouzan MI, Foster PJ, Al Herbish AS, Al Salloum AA, AIOmer AA, et al (2010) Prevalence of overweight and obesity in Saudi children and adolescents. Ann Saudi Med J 30: 203-208.

21. Scharla SH (1998) Prevalence of subclinical vitamin D deficiency in different European countries. Osteoporos Int 8: 7-12.

22. Gordon CM, DePeter KC, Feldman HA, Grace E, Emans SJ (2004) Prevalence of vitamin $\mathrm{D}$ deficiency among healthy adolescents. Arch Pediatr Adolesc Med 158: $531-537$. 
Citation: Al-Agha AE, Mahmoud AF, Alshein AA, Bukhari NH, Alaama MA, et al. (2016) Correlation among Bone Health Profile, Vitamin D Status and Body Weight among Children and Adolescents in the Western Region of Saudi Arabia. J Pat Care 2: 122. doi: 10.4172/2573-4598.1000122

23. Lehtonen-Veromaa M, Möttönen T, Irjala K, Kärkkäinen M, Lamberg-Allardt C et al (1999) Vitamin D intake is low and hypovitaminosis D common in healthy 9 to 15 year old Finnish girls. Eur J Clin Nutr 53: 746-751.

24. Guillemant J, Taupin P, Le HT, Taright N, Allemandou A, et al (1999) Vitamin $\mathrm{D}$ status during puberty in French healthy male adolescents. Osteoporos Int 10: $222-225$

25. Dahifar H, Faraji A, Yassobi S, Ghorbani A (2007) Asymptomatic rickets in adolescent girls. Indian J Pediatr 74: 571-575.

26. Du X, Greenfield H, Fraser DR, Ge K, Trube A, Wang Y (2001) Vitamin D deficiency and associated factors in adolescent girls in Beijing. Am J Clin Nutr 74: 494-500

27. Lapatsanis D, Moulas A, Cholevas V, Soukakos P, Papadopoulou ZL, et a (2005) Vitamin D: A necessity for children and adolescents in Greece. Calcif Tissue Int 77: 348-355

28. Moussavi M, Heidarpour R, Aminorroaya A, Pournaghshband Z, Amini M
(2005) Prevalence of vitamin D deficiency in Isfahani high school students in 2004. Horm Res 64: 144-148.

29. Ginty F, Cavadini C, Michaud PA, Burckhardt P, Baumgartner M, et al (2004) Effects of usual nutrient intake and vitamin $D$ status on markers of bone turnover in Swiss adolescents. Eur J Clin Nutr 58:1257-1265.

30. Turer CB, Lin H, Flores G (2013) Prevalence of vitamin D deficiency among overweight and obese US children. 131: e152-e161.

31. Kensarah OA, Azzeh FS (2012) Vitamin D status of healthy school children from Western Saudi Arabia. Pakistan Journal of Nutrition 11: 288-292.

32. Al-Jurayyan NAM, Al Jurayyan ANA, Hanan IO (2015) Alkaline phosphatase (ALP) activity as a marker for vitamin D deficiency. American Journal of Research Communication 3: 1-9.

33. Rajakumar K, Fernstrom JD, Holick MF, Janosky JE, Greenspan SL (2008) Vitamin D status and response to Vitamin $D(3)$ in obese vs. non-obese African American children. Obesity 16: 90-95. 